\title{
Ett unikt kulturflöde. Den svenska skönlitteraturens väg till Frankrike
}

Andreas Hedberg

Université d'Uppsala

Utflödet av skönlitteratur från Sverige (det vill säga översättningen av svensk skönlitteratur till andra språk) har hittills fått relativt begränsad uppmärksamhet inom litteraturvetenskapen. Den svenska forskningen om så kallad världslitteratur (world literature), som har vitaliserats de senaste åren, har främst inriktat sig på inflödet av skönlitteratur till Sverige, och trots flera goda specialstudier av det litterära utflödet under tidigare epoker saknar vi en systematisk bild av läget för de senaste decennierna.

Detta har blivit tydligt inte minst sedan svensk underhållningslitteratur (till exempel genom det så kallade svenska deckarundret) börjat spela en avgörande roll på den internationella bokmarknaden.

Vid Avdelningen för litteratursociologi i Uppsala bedrivs sedan några år tillbaka forskning inom profilområdet Svensk skönlitteratur i världen (SIV). Arbetet har hittills resulterat i antologin Svensk litteratur som världslitteratur (Svedjedal, 20I2). Profilområdets främsta syfte är att göra något åt vår bristfälliga kunskap om den svenska skönlitteraturens plats på den globala litterära marknaden.

Forskarna knutna till profilområdet SIV vill alltså - genom översättnings-, marknads- och förmedlingsstudier - utöka förståelsen för hur svensk skönlitteratur blir världslitteratur. Dessutom vill vi försöka finna det som är unikt för vart och ett av de stora språkområdena. Det vill säga: hur skiljer sig exempelvis Frankrike från Tyskland och USA när det gäller mottagandet av svensk litteratur, svenskundervisning och uppfattningen om Sverige och det svenska.

How to cite this book chapter:

Hedberg, A. 20 I 5. Ett unikt kulturflöde. Den svenska skönlitteraturens väg till Frankrike. In: Cedergren, M. et Briens, S. (eds.) Médiations interculturelles entre la France et la Suède. Trajectoires et circulations de I945 à nos jours. Pp. I I I-I I7. Stockholm: Stockholm University Press. DOI: http://dx.doi.org/IO.I6993/bad.i. License: CC-BY 


\section{Världslitteratur}

Vi återkommer ofta till begreppet världslitteratur. Och det är vi långt ifrån ensamma om. Forskare som David Damrosch och Franco Moretti har inspirerat alltfler litteraturvetare till studier av litteraturen som globalt fenomen. För att förstå hur vi inom profilområdet SIV arbetar med exempelvis litteraturflöden mellan Sverige och Frankrike är det viktigt att förstå världslitteraturen som problem.

Begreppet har blivit mycket populärt inom den internationella forskningen. Det hänger delvis ihop med globaliseringen, och nya förutsättningar för bokproduktion inom det som på engelska kallas "the global village”. Men det är också ett sätt att reagera på det som kallas humanioras kris, något som inte bara drabbat svenska litteraturvetare utan humanister i världen som helhet. Här finns ett nytt fält med konkreta problem där det fortfarande finns mycket kvar att göra. En återkommande metod är så kallad "distant reading”, ett perspektiv som ger ett överskådligt helikopterperspektiv på litteraturen. Närläsning blir ett minne blott; istället ägnar sig forskaren åt att studera litteraturens materiella villkor. För att förstå litteraturen, menar avståndsläsaren, måste vi sluta läsa böcker.

När man intresserar sig för frågan om kulturflöden, exempelvis mellan Sverige och Frankrike, är det nästan omöjligt att undvika begreppet världslitteratur. Tyvärr finns det en stor oenighet kring vad själva ordet betyder. Det användes av Goethe redan på ı 820-talet. När han pratade om Weltliteratur syftade han främst på nationallitteraturernas minskande betydelse i samband med det allt djupare samarbetet mellan intellektuella från till exempel Tyskland, Frankrike och England.

Idag finns det som sagt många tolkningar av begreppet. Vissa vill använda det för att tala om ett slags hyperkanon, det vill säga omistliga verk från hela världen, ungefär som den amerikanske litteraturvetaren Harold Blooms bekanta lista över världskanon. Andra använder ordet för att tala om summan av världens alla nationallitteraturer.

Det här menar jag är konservativa eller utopiska sätt att använda begreppet. Jag tror, liksom Moretti, att man måste tänka sig världslitteraturen som ett problem snarare än som ett objekt. Världslitteratur är alltså ett sätt att se på litteratur, och det vi då är särskilt intresserade av är hur litteratur korsar gränser, hur det sker och vad som då händer med litteraturen. Vad det är för slags litteratur spelar alltså mindre roll. 


\section{En föränderlig världsmarknad}

Litteraturens färdvägar förändras mycket snabbt just nu, och har gjort det $\mathrm{i}$ åtminstone ett par decenniers tid. Länge fanns väldigt tydliga, traditionella färdvägar - mönster som ständigt upprepades när svensk litteratur nådde en internationell marknad. Den vanliga färdvägen var via Danmark till Tyskland och därefter ut i världen. Danska och tyska var alltså betydelsefulla transitspråk, på vägen till exempelvis franska.

Vad som har hänt på sistone är att böcker idag kan ta helt nya vägar, och att resan ut i världen går betydligt snabbare. Ett exempel kan hämtas från deckarlitteraturen. Maria Lang, som debuterade I950, och blev en relativt framgångsrik författare såväl i Sverige som internationellt, översattes till åtta språk under 39 år. Hennes sentida kollega Camilla Läckberg, som debuterade 2004 och snabbt fick storartade framgångar i Sverige och utomlands, översattes till 24 språk på bara sju år. För Lang tog det 24 år att bli utgiven på franska, för Läckberg tog det 4 .

\section{Svenska författare i Frankrike}

Inom profilområdet SIV har jag personligen intresserat mig för den svenska litteraturens roll i Frankrike, som är speciell jämfört med motsvarande roll i andra länder. Det är förstås ett stort ämne, och än så länge rör det sig om ett forskningsprojekt som ännu inte genomförts. Mina slutsatser är alltså preliminära och projektets utgångspunkter är fortfarande öppna för diskussion.

Sverige och Frankrike har en lång tradition av kulturellt utbyte. Ofta har det förstås varit fråga om språkliga och kulturella fenomen som rört sig norrut, från Paris till Stockholm. Den svenska akademien, som modellerats efter den franska, är bara ett av många exempel. Men vi skall heller inte försumma de kulturprodukter som färdats den motsatta vägen. Svenskan är visserligen ett litet språk vad gäller antalet förstaspråkstalare (i den meningen återfinns svenskan på plats 90 bland världens språk), men som litterärt källspråk finns den enligt statistiken bland de tio största språken i världen (Svedjedal, 20 2: 36).

Det är naturligtvis anmärkningsvärt och jag tror att de svensk-franska kulturrelationerna har haft en viss betydelse för att det har blivit så. Översättningar till franska har - liksom översättningar till tyska helt enkelt spelat en stor roll för den svenska skönlitteraturens fortsatta spridning i världen. 
Frankrike var till exempel den första stora utländska marknaden för Stieg Larssons numera världskända kriminalromaner i Milleniumserien. Men det finns åtskilliga äldre exempel. Flera svenska författare, kanske främst August Strindberg, har gjort ambitiösa försök att slå igenom på den franska parnassen. Under ı 890-talets vurm för skandinavisk dramatik ("l'École Nordiste") spelades Fröken Julie (Mademoiselle Julie), Fadren (Père) och Fordringsägare (Créanciers) i Paris, där de möttes med ett relativt stort intresse, framför allt i pressen. Romanen En dåres försvarstal utgavs första gången på franska (Le plaidoyer d'un fou, I 895).

Också andra svenska författare slog igenom i Frankrike, dock utan Strindbergs personliga närvaro och engagemang. I905 publicerades den franska översättningen av Selma Lagerlöfs Gösta Berlings saga (och några år senare fick hon som första kvinna Nobelpriset), vilket blev början för en åtminstone halvsekellång storhetstid för Lagerlöfs författarskap i Frankrike.

Eyvind Johnson var på I920-talet bosatt i Paris; hans roman Stad $i$ ljus (I928) publicerades där (med titeln Lettre recommandée) redan 1927. Sex verk av Harry Martinson har översatts sedan I938. I954 utgavs Stig Dagermans roman Bränt barn på det franska prestigeförlaget Gallimard. Dagerman skulle komma att få mycket uppmärksamhet från franska kritiker och författarkollegor, något som betonats av Nobelpristagarna Jean-Marie Le Clézio och Patrick Modiano.

En första fråga man kan ställa sig är varför svenska författare och förläggare lagt ner så mycket tid och kraft på att närma sig den franska marknaden. En viktig delförklaring är föreställningen om Paris som "la capitale de l'univers littéraire", som den franska litteraturvetaren Pascale Casanova uttryckt det i sin inflytelserika bok La république mondiale des lettres (I999). Casanovas tes är att en författare som vill bli en del av världslitteraturen först måste erövra Paris. Denna tes är förstås drastiskt formulerad, och har också mött rättmätig kritik. Men oavsett om Casanova har rätt eller inte så är den föreställning hon formulerar tillräckligt välspridd för att påverka handlingsmönster i den litterära världen.

\section{Institutioner och deras betydelse}

Påfallande många svenska författare har alltså spelat en relativt stor roll i Frankrike. Men det särskilda förhållandet mellan svensk och fransk litteratur kan inte enbart förklaras med hänvisningar till sådana 
framgångsrika individer. Det finns andra, betydligt mer generella strukturer, som präglat utgivningen av svensk skönlitteratur på franska.

I Frankrike finns exempelvis förlag specialiserade på skandinavisk litteratur (Actes Sud med flera), samt tongivande nordister eller skandinavister, till exempel vid Sorbonne (Langues et littératures scandinaves), som på olika sätt bidrar till den franska bokbranschens kännedom om svenska författare.

Frankrike är det femte landet i världen när det gäller antal universitetsstudenter som studerar svenska - de är uppskattningsvis mellan 600 och 700 sammanlagt. Undervisningen finansieras delvis av Svenska institutet, som satsar mer pengar per student i Frankrike än i något annat land, med undantag för Ryssland och Polen.

Den franska skandinavistiken har dessutom ett annat fokus än till exempel den engelska. Medan man i England intresserar sig betydligt mer för filologi och ett äldre germanskt kulturarv som är gemensamt för svenskar och engelsmän, fokuserar man i Frankrike mer på nutida förhållanden. Skandinavistiken har alltså inte samma roll som stöddisciplin för historia och kulturhistoria. Frågar man de som studerar svenska i Frankrike hur de planerar att använda sina kunskaper är det många som svarar att de vill arbeta som översättare.

Både från fransk och svensk sida finns också statliga stödformer; översättningsbidrag (från till exempel Kulturrådet) och resebidrag (från till exempel Svenska institutet) bidrar till kontakterna mellan franskt och svenskt kulturliv. Dessa bidrag kan i sin tur ytterligare förbättra möjligheterna för de personliga kontakter som sedan länge spelat en avgörande roll för förmedlingen av litteratur mellan Sverige och Frankrike.

Statistik från Kulturrådet visar att franska förläggare och översättare är mycket aktiva när det gäller att söka översättningsstöd ( I7 ansökningar 20I I och lika många 20I2, vilket placerar Frankrike på plats fyra respektive fem på listan över länder med flest ansökningar).

\section{Frankrike som undantag}

Vad har då allt detta fått för effekt när man statistiskt undersöker den svenska litteraturens plats i Frankrike? Jo, det finns intressanta skillnader mellan Frankrike och de andra världsspråken. Ett exempel är andelen barn- och ungdomslitteratur. Litteratur för barn och ungdom är Sveriges utan jämförelse viktigaste bidrag till världslitteraturen. Ser man till det totala antalet utgåvor av svensk barn- och ungdomslitteratur på 
samtliga utländska språk utgör de ungefär 60 procent av den totala utgivningen av svensk skönlitteratur. Andelen varierar förstås på olika språkområden. Engelskan ligger nära genomsnittet med 57 procent. På japanska är andelen så hög som 84 procent. Franskan däremot, sticker ut med en betydligt lägre andel, bara 39 procent. (Sifferuppgifterna i detta avsnitt är baserade på sökningar i Kungl. bibliotekets bibliografi Suecana Extranea; för en diskussion om denna, se mitt bidrag i Svedjedal, 20I2.)

Det är också anmärkningsvärt att kanoniserade författarskap blivit särskilt väl spridda på den franska bokmarknaden. Astrid Lindgren (som dominerar mycket stort på de flesta av målspråken) överträffas på franska klart av Selma Lagerlöf, samtidigt som August Strindbergs ställning är lika stark som Lindgrens. Även nu verksamma författare som kan räknas till den kanoniserade litteraturen har fått jämförelsevis stor spridning i Frankrike, exempelvis P. O. Enquist, Lars Gustafsson och Kerstin Ekman.

En bidragande orsak torde vara det relativt tidigt befästa kulturella utbytet mellan Sverige och Frankrike, vilket lagt grunden för en betydligt bredare utgivning. Det franska språkets höga status på det litterära fältet har sannolikt också varit betydelsefull. Författare vars verk placerats på vad Pierre Bourdieu har kallat den begränsade produktionens fält - bland vilka endast ett fåtal varit författare av barn- och ungdomslitteratur - bör ha efterfrågat översättningar till just franska. Deras personliga engagemang (till exempel Strindbergs) tycks också ha burit frukt.

Enskilda personliga insatser från framgångsrika översättare som C. G. Bjurström (I9I9-200I) har också bidragit till den stora andelen vuxenlitteratur i litteraturflödet mellan Sverige och Frankrike. Bjurströms stora betydelse framgår mycket tydligt om man ser kvantitativt på hans verksamhet. Enligt min egen uppskattning har han stått bakom eller medverkat till cirka 7 procent av det samlade antalet översättningar av svensk skönlitteratur till franska, vilket förstås är anmärkningsvärt.

Andra flitiga översättare har också spelat en stor roll för kulturutbytet mellan Sverige och Frankrike. Jag vill särskilt nämna Philippe Bouquet ( 177 verk), Marc de Gouvenain och Lena Grumbach (80 verk), och Elena Balzamo (3 I verk). (Siffrorna gäller antalet översatta verk av svenska författare som finns förtecknade i Denis Ballus bibliografi Lettres Nordiques. Une bibliographie, I720-2013.) 


\section{Början, inte slutet}

Alla de faktorer som jag nu har nämnt - skandinavistiken, förläggarna, stödformerna, översättarna - behöver förstås utredas ytterligare. Och framför allt är jag förstås intresserad av hur de hänger ihop.

Exempel på frågeställningar är: Hur får förläggare och översättare i Frankrike kännedom om svensk skönlitteratur? Vilka relationer och beslut präglar översättarnas val av källtexter? Vilka institutionella och ekonomiska villkor präglar utgivningen? Vilken bakgrund har de centrala aktörer som arbetar för svensk litteratur i Frankrike?

Än så länge är det här frågor utan uttömmande svar. För att finna de här svaren krävs mer arbete, och samarbete med aktörer på flera olika fält. Och det är just det här, frågorna utan svar, som känns så stimulerande. Franco Moretti har lite elakt sagt att det är frågorna utan svar som är framtidslöften, särskilt på ett fält som vårt, där vi - enligt honom - är vana vid att bara ställa de frågor som vi redan vet svaret på.

Moretti, som lagt så mycket kraft på att utveckla och bekantgöra "distant reading" som metod, understryker att detta helikopterperspektiv främst syftar till att finna frågorna för fortsatta undersökningar. För att verkligen finna svaren, menar han, måste forskaren överge "the quantitative universe”. På hans forskningsfält råder vad han kallar för "the total heterogeneity of problem and solution". Den kvantitativa metoden skapar frågor, svaren kräver djuplodande undersökningar av en helt annan karaktär.

När det gäller kulturflöden mellan Sverige och Frankrike krävs en kvalitativ undersökning, utformad med ledning av de frågor som formulerats ovan, av alla de instanser som nämnts i denna uppsats: skandinavistiken, förläggarna, stödformerna, översättarna. Där finns förklaringen till de säregna litterära band som förbinder Sverige med Frankrike.

\section{Bibliographie}

Casanova, P. (1999), La République mondiale des lettres. Paris : Seuil.

Moretti, F. (2008), Graphs, Maps, Trees. Abstract Models for Literary Historia, London : Verso.

Svedjedal, J (éd.), Svensk litteratur som världslitteratur. En antologi. Uppsala : Kph, Uppsala. 